\title{
Editorial Note: Web Data Analysis in Pervasive Multimedia Environment
}

Multimedia Tools and Applications gratefully acknowledges the editorial work of the scholars listed below on the special issue entitled, "Web Data Analysis in Pervasive Multimedia Environment."

Of 21 papers submitted to this issue, 14 were eventually accepted after the stringent peerreview process.

Dr. Neil Y. Yen (Corresponding Guest Editor)

School of Computer Science and Engineering

University of Aizu, Japan

neil219@gmail.com

https://sites.google.com/site/nywyen/

\section{Dr. Maiga Chang}

School of Computing and Information Systems

Athabasca University, Canada

maigac@athabascau.ca

http://scis.athabascau.ca/scis/staff/faculty.php?id=maigac

\section{Dr. Kurosh Madani}

University PARIS-EST Creteil (UPEC), France

madani@u-pec.fr

http://www.researchgate.net/profile/Kurosh_Madani/ 